\title{
Pengembangan Permainan Untuk Pembelajaran Angka Dan Huruf Hijaiyah Berbasis Android
}

\author{
Andhika Hanifa Naufaliawan ${ }^{1)}$, Rizal Isnanto ${ }^{2)}$, Ike Pertiwi Windasari ${ }^{2)}$ \\ Program Studi Sistem Komputer Fakultas Teknik Universitas Diponegoro \\ Jalan Prof. Sudharto, Tembalang, Semarang, Indonesia \\ naufaliawandhika@gmail.com
}

\begin{abstract}
The development of increasingly advanced technology has a vital role in all sectors of management, which includes the processing of data. Moreover, with the development of the internet is so fast these days that requires every person to obtain information quickly and accurately. Associated with it then there is a game that has grown rapidly with variations of each preparation This application uses the software Construct 2 as editor. Multimedia Development Life Cycle used as methodology for developing this game. Stages of research method, namely literature, game design, game implementation, testing, and analysis. User applications can execute all the menus contained in the application "Belajar Angka dan Huruf Hijaiyah". With this application android-based user can exercise anytime and anywhere, and this application can run well when tested using black-box and got positive results when tested to application user.
\end{abstract}

Keywords: game, technological development, education, android

\section{PENDAhUluan}

$\mathrm{P}$ ENDIDIKAN adalah usaha sadar dan terencana untuk mewujudkan suasana belajar dan proses pembelajaran agar peserta didik secara aktif mengembangkan potensi dirinya untuk memiliki kekuatan spiritual keagamaan, pengendalian diri, kepribadian, kecerdasan, akhlak mulia, serta keterampilan yang diperlukan dirinya, masyarakat, bangsa dan negara. Saat ini pendidikan dan teknologi mempunyai peran penting dalam mencerdaskan kehidupan bangsa.

Teknologi di masa kini memberikan pengaruh yang sangat besar terhadap perkembangan anak. Tidak jarang ditemukan anak usia sekolah dasar sudah mahir bermain game di perangkat seluler. Melalui penelitian ini, penulis bermaksud mengembangkan permainan interaktif pada Android dengan tema pendidikan angka dan huruf hijaiyah, untuk mengenalkannya kepada anak usia dini dengan cara yang menyenangkan dan mudah dipahami. Karena dengan adanya permainan berbasis Android tersebut dapat mengoptimalkan penggunaan sebuah perangkat seluler yang sebagian besar hanya untuk sekedar bermain tapi juga dapat digunakan sebagai sarana pembelajaran yang sangat mudah digunakan dimanapun.

Media adalah segala sesuatu yang dapat digunakan untuk menyalurkan pesan dari pengirim ke penerima sehingga dapat merangsang pikiran, perasaan, perhatian, dan minat serta perhatian siswa sedemikian rupa sehingga proses belajar mengajar terjadi.
Jadi, media dirancang sedemikaian rupa agar dapat menarik perhatian siswa sehunggan siswa dapat dengan mudah memahami pelajaran yang disampaikan oleh guru mereka.

Untuk itu, dengan dilakukannya penelitian ini, diharapkan dapat menjadi salah satu media pembelajaran Agama yang menyenangkan dan mudah dipahami bagi anak-anak tingkat sekolah dasar sehingga anak-anak yang dewasa ini kerap menggunakan gadget sudah tidak hanya menggunakannya untuk bermain permainan umum, melainkan ada unsur pendidikan di dalamnya.

\section{DASAR TEORI}

\section{A. Multimedia}

Multimedia adalah proses penggunaan komputer untuk menyajikan dan menggabungkan teks, suara, gambar, animasi, dan video dengan alat bantu (tool) dan berkomunikasi. Multimedia juga diadopsi oleh dunia game. Multimedia dimanfaatkan juga dalam dunia pendidikan dan bisnis. Di dunia pendidikan, multimedia digunakan sebagai sarana media pengajaran, baik dalam kelas maupun secara sendiri-sendiri. Di dunia bisnis, multimedia digunakan sebagai media profil perusahaan, profil produk bahkan sebagai media kios informasi dan pelatihan dalam sistem e-learning ${ }^{[3]}$.

Di bawah ini dijelaskan mengenai elemen-elemen yang terdapat dalam multimedia.

1) Teks

Teks adalah elemen paling dasar dari seluruh program pengolah kata juga aplikasi multimedia. Teks digunakan untuk menjabarkan atau menyampaikan informasi tertentu. Teks tersusun dari beberapa simbol, abjad besar dan kecil, serta angka. Dalam kenyataannya multimedia menyajikan informasi dengan cepat, karena tidak diperlukan membaca secara rinci dan teliti. Kebanyakan sistem multimedia dirancang dengan menggunakan teks karena teks merupakan sarana yang efektif untuk mengemukakan ideide dan menyediakan instruksi-instruksi kepada user (pengguna).

2) Grafik (Image)

Grafik merupakan sarana sekaligus elemen multimedia yang berguna untuk mengungkapkan suatu informasi secara visual. Grafik menjadi nilai dan unsur tambah suatu penyajian data. Gambar digunakan dalam presentasi multimedia untuk menarik perhatian dan dapat mengurangi kebosanan, apabila dibandingkan dengan teks. Manusia sangat berorientasi pada visual dan gambar merupakan sarana yang sangat baik untuk menyajikan 
informasi.

3) Suara (Audio)

Suara adalah elemen paling unik yang tersedia diantara keseluruhan elemen multimedia. Elemen ini menyempurnakan aplikasi multimedia dengan kemampuan audionya. Bila elemen lain memberikan informasi kepada pengguna dengan menggunakan indra penglihatan maka elemen suara akan memberikan informasi dan memanjakan pengguna dengan menggunakan indra pendengaran.

4) Video

Video akan membuat aplikasi multimedia lebih hidup. Namun kendala yang dihadapi dalam memanfaatkan media ini adalah ukuran berkas yang terlalu besar. Untuk itu, diperlukan perangkat lunak lain untuk memperkecil ukuran berkas video.

5) Animasi

Animasi adalah urutan gambar atau image yang ditampilkan secara berurutan sehingga akan menimbulkan kesan gambar tersebut bergerak, kesan bergerak ini didapat akibat adanya peralihan dari satu gambar ke gambar lainnya dalam satu satuan waktu yang disebut frame per second (fps) dalam pengertian ada beberapa jumlah frame yang berupa gambar atau image untuk satu detik animasi. Dalam arti lain animasi adalah persepsi yang terjadi akibat perpindahan frame dalam satu waktu ${ }^{[4]}$.

\section{B. Pembelajaran Bahasa Arab}

Pengajaran bahasa Arab berkait erat dengan aspek-aspek pengajarannya itu sendiri yang mencakup pendekatan, metode, dan teknik-tekniknya. Edward M. Anthony menjelaskan bahwa pendekatan sebagai aksi yang merupakan serangkaian asumsi hakikat bahasa dan pembelajaran bahasa. Asumsi yang berhubungan dengan pembelajaran bahasa mencakup aspek mendengar/menyimak (al-Istima'), bercakap-cakap (al-kalam), membaca (al-qiraat), dan menulis (al-kitabah). Empat keterampilan ini selanjutnya akan membangun metode-metode atau model-model dalam pengajaran Bahasa $\mathrm{Arab}^{[1]}$.

\section{Android}

Menurut Dodit Suprianto Android adalah sistem operasi bergerak (mobile operating system) yang mengadopsi sistem operasi Linux, namun telah dimodifikasi. Android di ambil alih oleh Google pada tahun 2005 dari Android, Inc sebagai bagian dari strategi untuk mengisi pasar sistem operasi bergerak. Google mengambil alih seluruh hasil kerja android termasuk tim yang mengembangkan Android ${ }^{[5]}$.

Google menginginkan agar android bersifat terbuka dan gratis, oleh karena itu hampir setiap kode program Android diluncurkan berdasarkan lisensi open source Apache yang berarti bahwa setiap orang yang ingin menggunakan Android dapat men-download penuh source code nya.

Disamping itu produsen perangkat keras juga dapat menambahkan extension-nya sendiri ke dalam android sesuai kebutuhan produk mereka.

\section{Construct 2}

Construct 2 adalah produk buatan Scirra, perusahaan yang berasal dari London, Inggris. Construct 2 yang memang didesain dengan banyak fitur. Game builder ini sebenarnya dirancang untuk game berbasis $2 \mathrm{D}$.

Construct 2 menyediakan 70 visual effect yang menggunakan engine WebGL dan juga dilengkapi dengan 20 built-in plugin dan behaviours (perilaku). Dengan begitu pengembang dapat melakukan hal-hal seperti :

a.Menambah sprite animasi

b.Objek teks

c. Mengkoneksikan ke Facebook

d.Menambah musik

e.Manipulasi penyimpanan data game

f. dan penambahan efek-efek grafis layaknya Adobe Photoshop

\section{E. Audacity}

Audacity adalah aplikasi perangkat lunak untuk merekam dan menyunting suara. Aplikasi ini bersifat open source dan sehingga dapat berjalan pada berbagai sistem operasi.

Audacity mampu mengoreksi suara tertentu, atau sekedar menambahkan berbagai efek yang disediakan. Audacity juga digunakan untuk memotong suara, menambahan bahkan mengkonversi ke file lain, diantaranya MP3, Ogg, dan Wave $9^{[9]}$.

\section{F. Corel Draw}

Corel Draw adalah sebuah program komputer yang melakukan editing pada garis vektor. Program ini dibuat oleh Corel, sebuah perusahaan software yang berkantor pusat di Ottawa, Kanada. Corel draw memiliki kegunaan untuk mengolah gambar, oleh karena itu banyak digunakan pada pekerjaan dalam bidang publikasi atau percetakan ataupun pekerjaan di bidang lain yang membutuhkan proses visualisasi $^{[10]}$.

\section{G. Skala Likert}

Skala Likert menurut Djaali (2008:28) ialah skala yang dapat dipergunakan untuk mengukur sikap, pendapat, dan persepsi seseorang atau sekelompok orang tentang suatu gejala atau fenomena pendidikan. Skala Likert adalah suatu skala psikometrik yang umum digunakan dalam kuesioner, dan merupakan skala yang paling banyak digunakan dalam riset berupa survei.

\section{H. Metodologi Pengembangan Multimedia}

Metode yang digunakan dalam pengembangan multimedia ini adalah Multimedia Development Life Cycle. Pengembangan metode multimedia ini dilakukan berdasarkan enam tahap, yaitu concept (konsep), design (rancangan), material collecting (pengumpulan materi), assembly (pembuatan), testing (pengujian), dan distribution (pendistribusian). Keenam tahap ini tidak harus berurutan dalam praktiknya, tahap-tahap tersebut dapat saling bertukar posisi. Meskipun begitu, tahap concept memang harus menjadi hal yang pertama kali dikerjakan (Luther, 1994).

Tahap pengembangannya dapat dilihat seperti pada Gambar 1.

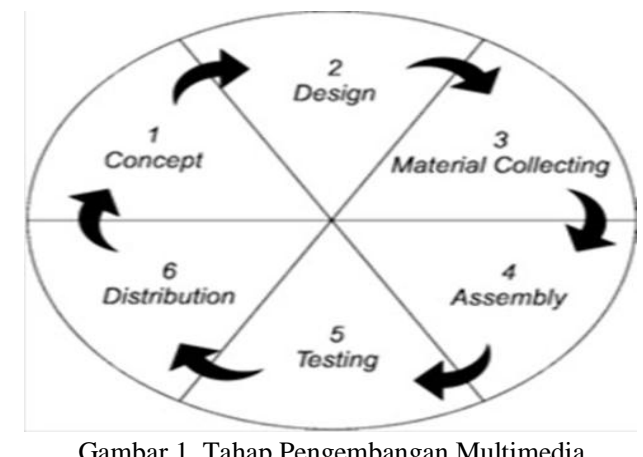

Gambar 1. Tahap Pengembangan Multimedia 


\section{Konsep (Concept)}

Dalam tahap konsep yang perlu diperhatikan adalah menentukan tujuan, termasuk identifikasi para pengguna, macam aplikasi (presentasi, interaktif, dan lain-lain), tujuan aplikasi (informasi, hiburan, dan lain-lain), dan spesifikasi umum serta memahami karakteristik pengguna. Konsep ini dapat mengacu pada kebutuhan pengguna dan kemampuan sistem dalam berkomunikasi. Selain itu, tahap ini juga akan menentukan jenis aplikasi (presentasi, interaktif, dan lain-lain). Desain (Design)

Tahap desain (perancangan) adalah membuat spesifikasi secara rinci mengenai arsitektur proyek, gaya, dan kebutuhan material untuk proyek. Menjadikan sebuah proyek menjadi sangat akurat antara teori dan yang terjadi di lapangan.

\section{Pengumpulan Materi (Material Collecting)}

Material Collecting adalah tahap pengumpulan bahan yang sesuai dengan kebutuhan yang dikerjakan. Bahan-bahan tersebut, antara lain gambar clipart, foto, animasi, video, audio, dan lain-lain yang dapat diperoleh secara gratis atau dengan pemesanan kepada pihak lain sesuai dengan rancangannya. Tahap ini dapat dikerjakan secara paralel dengan tahap assembly. Namun, pada beberapa kasus, tahap material collecting dan tahap assembly akan dikerjakan secara linear dan tidak paralel.

\section{Pembuatan (Assembly)}

Tahap pembuatan merupakan tahap pembuatan seluruh objek multimedia. Pembuatan aplikasi berdasarkan storyboard, flowchart view, struktur navigasi, atau diagram objek yang berasal dari tahap desain. Tahap ini biasanya menggunakan perangkat lunak authoring, seperti Macromedia Director. Selain itu, Macromedia Flash atau produk Open Source yang gratis, yaitu Sophie yang dapat berjalan di Linux maupun di Mac OS X juga dapat digunakan.

Pengujian (Testing)

Pengujian dilakukan setelah selesai tahap pembuatan dan seluruh data telah dimasukkan. Tahap pertama pada tahap ini disebut tahap pengujian alpha (alpha test) yang pengujiannya dilakukan oleh pembuat atau lingkungan pembuatnya sendiri. Setelah lolos dari pengujian alpha, pengujian beta yang melibatkan pengguna akhir akan dilakukan.

\section{Distribusi (Distribution)}

Bila aplikasi multimedia akan digunakan dengan mesin yang berbeda, penggandaan menggunakan floppy disk, CD-ROM, tape, atau distribusi dengan jaringan internet sangat diperlukan. Tahap distribusi juga merupakan tahap evaluasi terhadap suatu produk multimedia yang sudah jadi supaya menjadi lebih baik. Hasil evaluasi ini dapat digunakan sebagai masukan untuk tahap concept pada produk selanjutnya ${ }^{[2]}$.

\section{PERANCANGAN SISTEM}

\section{A. Konsep}

Konsep permainan angka dan huruf hijaiyah berbasis android ini dibuat untuk pembelajaran dasar dalam Bahasa Arab untuk anak-anak usia dini sehingga mereka mudah memahami melalui cara yang interaktif. Aplikasi ini memiliki 3 bagian. Yang pertama bagian untuk pembelajaran, pada bagian pertama ini akan terdapat angka dan huruf hijaiyah disertai dengan nama dari masing masing. Yang kedua adalah menghafal angka dan huruf hijaiyah, dalam proses menghafal di bagian dibuatlah sebuah tebak gambar. Dimana di setiap levelnya terdapat 2 angka atau huruf hijaiyah yang dibuat acak dan tertutup. Yang ketiga yaitu permainan, permainan sendiri dibagi menjadi dua macam permainan. Permainan pertama yaitu menjawab angka dan huruf hijaiyah, dengan terdapat tiga Jurnal Teknologi dan Sistem Komputer, Vol.3, No.2, April 2015 pilihan jawaban disertai nilai satu untuk setiap jawaban yang benar. Permainan ini dapat dimainkan oleh semua kalangan dan jenis kelamin, namun lebih dikhususkan untuk anak-anak sekolah dasar, dengan harapan agar anak-anak kecil paham mengenai pembelajaran Agama.

\section{B. Desain}

Dalam tahap desain ini dibagi menjadi tiga macam yaitu perancangan berbasis multimedia, desain struktur navigasi dan desain berorientasi objek.

\section{Perancangan Berbasis Multimedia}

Berikut ini merupakan storyboard dari Layout awal yang digambarkan pada Gambar 2, storyboard dibuat berdasarkan konsep pembuatan storyboard menurut Luther-Sutopo.

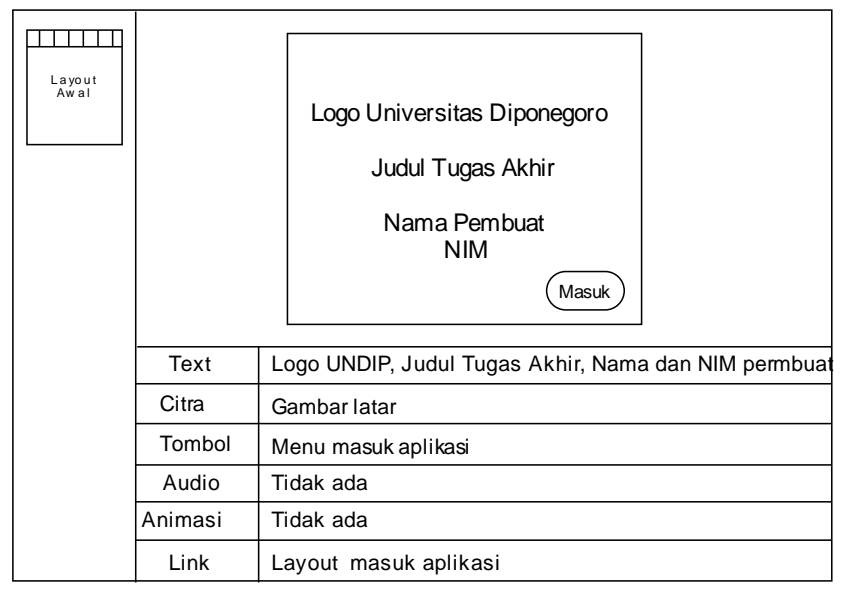

Gambar 2. Bagan Perancangan Permainan

\section{Desain Struktur Navigasi}

Struktur navigasi memberikan gambaran link dari halaman satu ke halaman lainnya. Dalam permainan ini desain struktur navigasi yang digunakan adalah struktur navigasi dengan hierarki model, dimana pada model ini diadaptasi dari topdown design. Konsep navigasi ini dimulai dari satu node yang menjadi halaman awal, dari halaman tersebut dapat dibuat beberapa cabang lagi. Berikut struktur navigasi pada perancangan permainan angka dan huruf hijaiyah yang dijelaskan pada Gambar 3.

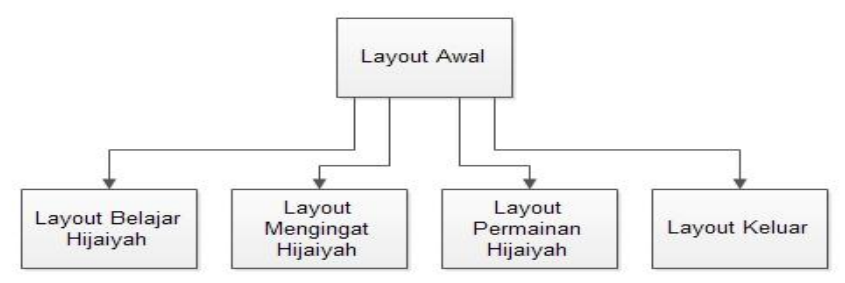

Gambar 3. Struktur navigasi pada perancangan permainan

\section{Perancangan Berorienstasi Objek}

Analisis dan desain berorientasi objek adalah cara baru dalam memikirkan suatu masalah dengan menggunakan model yang dibuat menurut konsep sekitar dunia nyata. Dasar pembuatan adalah objek, yang merupakan kombinasi antara struktur data dan perilaku dalam satu entitas. Terkait dengan itu permainan ini terdiri dari beberapa Layout dan pada setiap Layout mempunyai bermacam-macam objek seperti audio, tombol, movie clip dan grafik, dan pada setiap objek tersebut dapat memiliki hierarki objek yang lain.

Struktur hierarki objek pada Layout pertama akan dijabarkan pada Gambar 4. 


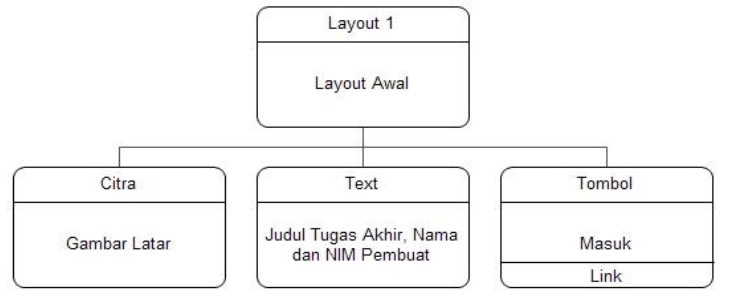

Gambar 4. Struktur Hierarki Objek pada Layout awal

\section{Flowchart}

Flowchart yang menunjukkan perubahan tampilan pada suatu layout. Transisi dari satu Layout ke Layout lainnya dijelaskan, hubungan antara satu Layout dengan Layout yang lain yang dinyatakan dengan garis berikut tanda panah. Flowchart view banyak digunakan dalam pengembangan multimedia interaktif. Berikut merupakan flowchart view dari pengembangan permainan untuk pembelajaran angka dan huruf hijaiyah yang akan dibuat, dapat dilihat pada Gambar 5.

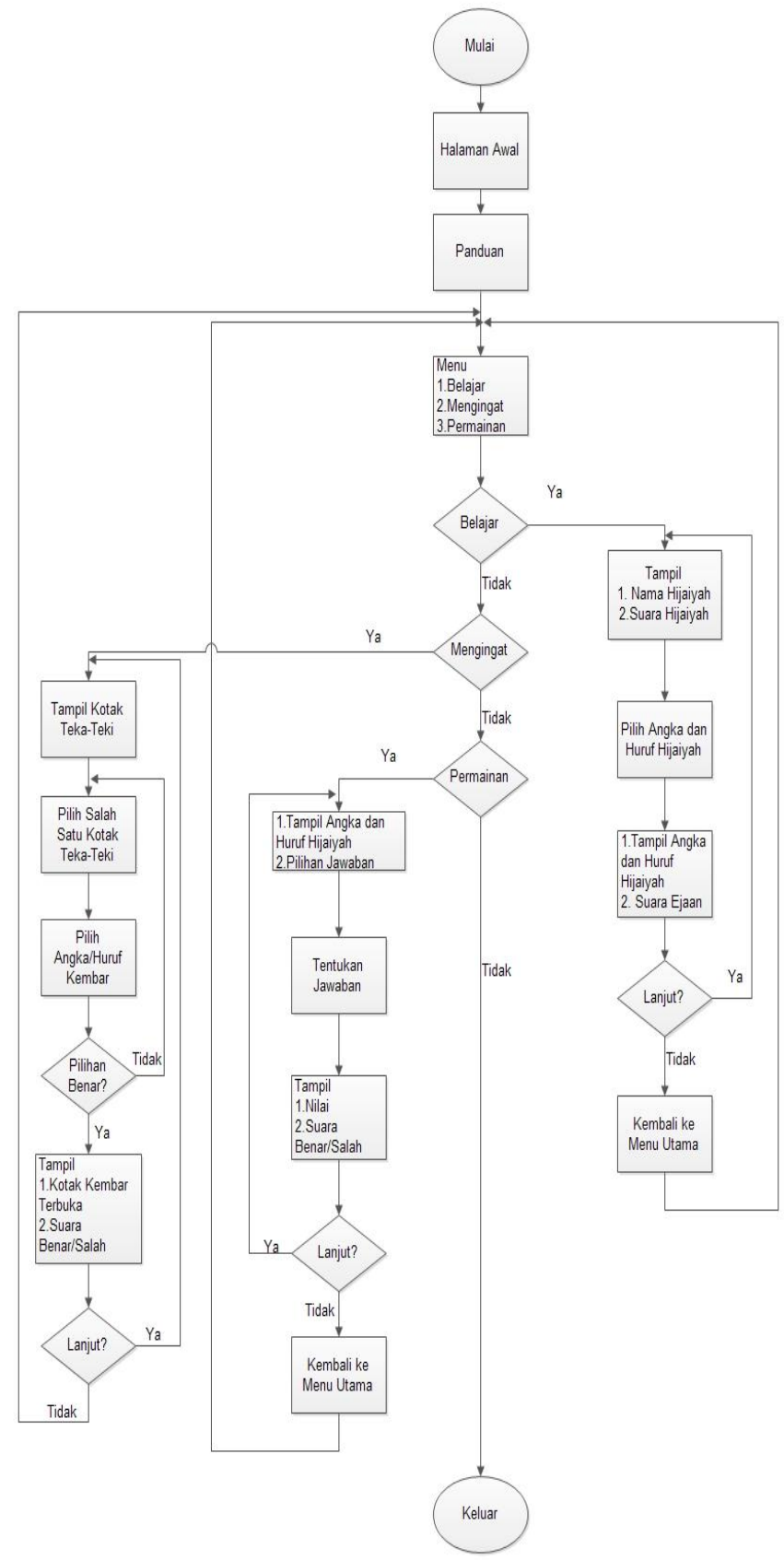

Gambar 5. Flowchart View rancangan permainan

\section{Pembuatan Dan Pengujian}

Pembuatan permainan dilakuan dengan membuat setiap Layout dan Event sheetnya, dimulai dari Layout awal lalu di lajutkan ke Layout menu dan seterusnya secara berurutan. Pembuatan disesuaikan dengan rancangan aplikasi yang telah dibuat, serta menggunkan bahan yang telah dikumpulkan pada tahap pengumpulan bahan.

\section{Pembuatan}

Proses pembuatan pertama dimulai dengan pembuatan Layout awal, dimana Layout awal berisi logo Universitas Diponegoro, judul permainan dan profil pembuat. Layout awal ini memiliki 2 objek, yang pertama objek sprite yang digunakan untuk gambar latarnya dan yang kedua objek sprite masuk yang berfungsi sebagai tombol masuk ke menu utama. Gambar 6 merupakan penjelasan objek-objek yang ada pada Layout awal.

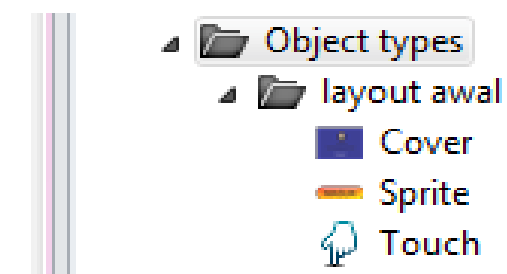

Gambar 6. Objek-objek yang terdapat pada layout awal

Setelah memasukkan objek-objek yang dibutuhkan, tahap selanjutnya adalah menyusun objek sesuai tampilan yang diinginkan. Gambar 7 merupakan gambar pembuatan tampilan pada Layout awal

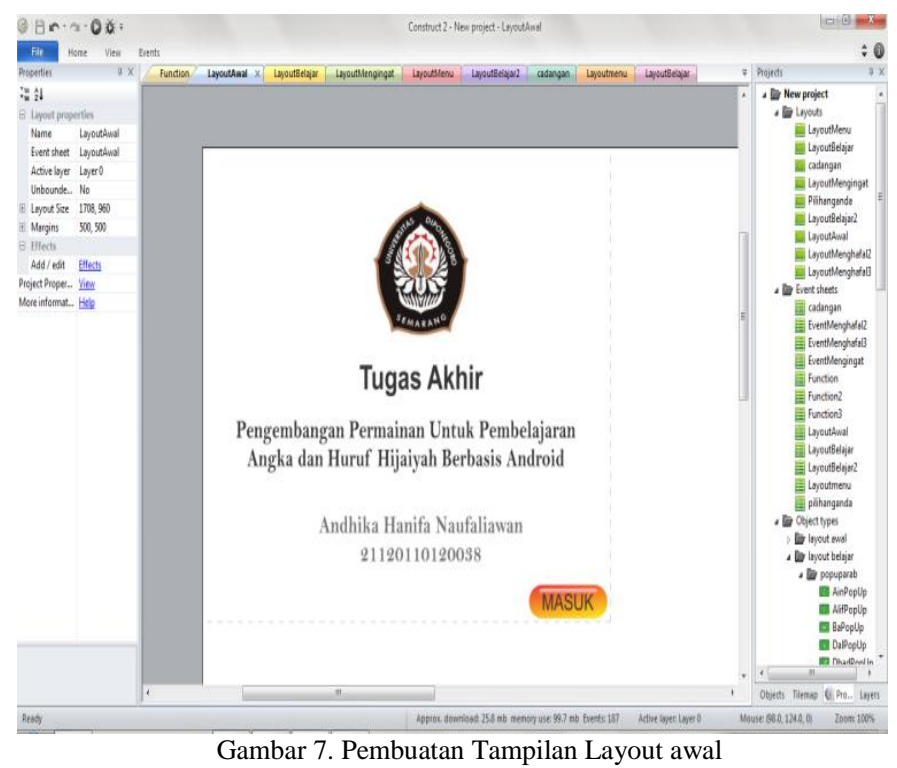

Setelah tampilan dibuat, tahap selanjutnya yaitu membuat Event untuk memberi perilaku objek-objek di Layout awal pada Event sheet Layout awal. Gambar 8 merupakan gambar pembuatan Event sheet Layout awal.

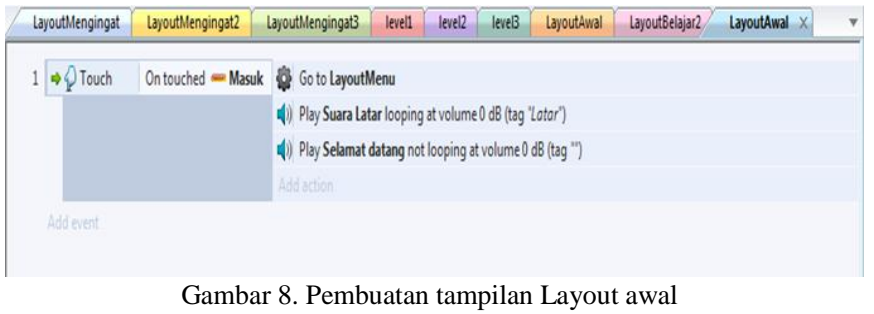

Gambar 8. Pembuatan tampilan Layout awal 
Kemudian jika objek dan Event sudah selesai, maka ketika program dieksekusi, akan muncul tampilan seperti pada Gambar 9.

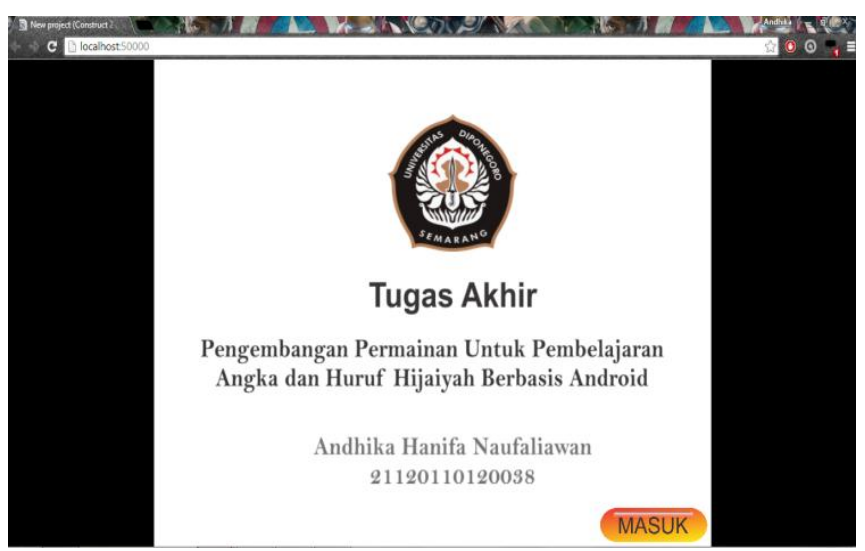

Gambar 9. Pembuatan tampilan Layout awal

\section{Pengujian}

Pengujian permainan belajar angka dan huruf hijaiyah dilakukan dengan menggunakan metode black-box, dengan kata lain pengujian yang menekankan pada fungsionalitas dari permainan. Tahap ini berisi serangkaian pengujian fungsi dan tombol pada permainan. Tingkat keberhasilan pengujian, diukur dari terpenuhinya spesifikasi kebutuhan dan skenario permainan. Pengujian permainan dijalankan pada smartphone yang menggunakan sistem operasi Android. Cara pengujiannya hanya dilakukan dengan menjalankan permainan, kemudian diamati apakah hasilnya sesuai dengan spesifikasi kebutuhan.

TABEL I

Pengujian APliKasi SeCARA KeSEluRuhan

\begin{tabular}{lllc}
\hline \hline \multicolumn{1}{c}{$\begin{array}{c}\text { Nama } \\
\text { Pengujian }\end{array}$} & \multicolumn{1}{c}{$\begin{array}{c}\text { Bentuk } \\
\text { Pengujian }\end{array}$} & \multicolumn{1}{c}{$\begin{array}{c}\text { Hasil yang } \\
\text { Diharapkan }\end{array}$} & $\begin{array}{c}\text { Hasil } \\
\text { Pengujian }\end{array}$ \\
\hline Pengujian & Menekan & Tampil halaman & Berhasil \\
Pengujian & Menekan & Tampil halaman & Berhasil \\
menu belajar & tombol belajar & belajar hijaiyah & \\
Pengujian & Menekan & Tampil popup & Berhasil \\
menu & tombol & level mengingat & \\
mengingat & mengingat & hijaiyah & \\
Pengujian & Menekan & Tampil halaman & Berhasil \\
menu & tombol & permainan & \\
permainan & permainan & hijaiyah & Berhasil \\
Pengujian & Menekan & Keluar dari & \\
menu keluar & tombol keluar & aplikasi & \\
\hline \hline
\end{tabular}

\section{Pengujian Aplikasi Menggunakan Kuesioner}

Untuk mengetahui secara langsung manfaat aplikasi bagi pengguna, penulis melakukan survey skala penilaian atau rating scale yang kemudian dihitung menggunakan skala Likert untuk mengubahnya dalam bentuk persentase.

Proses pengujian dilakukan dengan cara meminta responden untuk menjawab 4 sample pertanyaan dimana setiap pertanyaan terdapat 5 pilihan jawaban, yaitu Sangat Tidak Setuju, Tidak Setuju, Netral, Setuju,dan Sangat Setuju.

Pada setiap sample pertanyaan yang diberikan, untuk penilaian Sangat Tidak Setuju diberi bobot skor 1, Tidak
Setuju diberi bobot skor 2, dan begitu seterusnya. Digunakan rumus skala Likert sebagai berikut:

$$
Y=\frac{X}{\text { skor ideal }} \times 100 \%
$$

Keterangan :

$\mathrm{X}=$ Jumlah frekuensi dikalikan dengan nilai kategori jawaban

Skor ideal $=$ Nilai tertinggi dikalikan dengan jumlah sampel $\mathrm{Y}=$ Nilai persentase yang dicari

Tabel II menunjukkan hasil pengujian kuesioner yang diberikan dengan sample pertanyaan aplikasi "Belajar Angka dan Huruf Hijaiyah" mudah dalam penggunaannya, setelah responden menggunakan aplikasi ini dan kemudian dihitung nilainya dengan menggunakan rumus skala Likert.

TABEL II

HASIL PENGUJIAN KUESIONER

\begin{tabular}{ccccc}
\hline \hline Soal & Keterangan & Skor & Responden & Skor Responden \\
\hline 1 & $\begin{array}{c}\text { Sangat Tidak } \\
\text { Setuju }\end{array}$ & 1 & 0 & 0 \\
& Tidak Setuju & 2 & 0 & 0 \\
Netral & 3 & 7 & 21 \\
& Setuju & 4 & 2 & 8 \\
& Sangat Setuju & 5 & 0 & 0 \\
& Jumlah & & 9 & 29 \\
\hline \hline
\end{tabular}

Berdasarkan perhitungan menurut rumus skala Likert maka didapatkan hasil sebagai berikut ini.

$$
Y=\frac{29}{45} \times 100 \%=64 \%
$$

Berdasarkan hasil persentase nilai di atas, maka dapat disimpulkan bahwa berdasarkan pertanyaan yang diberikan, responden mudah dalam menggunakan aplikasi ini. Hal ini dapat dilihat sesuai dengan Gambar 10 interval penilaian seperti berikut.

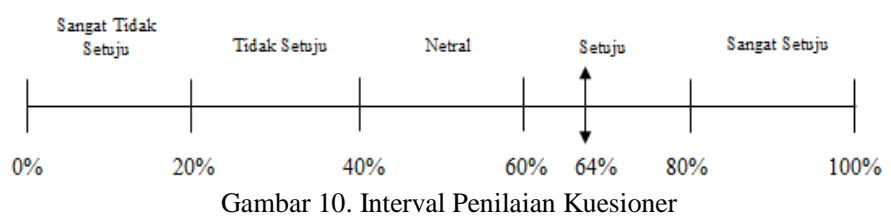

Tabel III menunjukkan hasil pengujian kuesioner yang diberikan dengan sample pertanyaan tampilan Aplikasi "Belajar Angka dan Huruf Hijaiyah" secara keseluruhan bagus dan menarik, setelah responden menggunakan aplikasi ini dan kemudian dihitung nilainya dengan menggunakan rumus skala Likert.

TABEL III

HASIL PENGUJIAN KUESIONER

\begin{tabular}{ccccc}
\hline \hline Soal & Keterangan & Skor & Responden & Skor Responden \\
\hline 1 & Sangat Tidak & 1 & 0 & 0 \\
Setuju & Tidak Setuju & 2 & 1 & 2
\end{tabular}




\begin{tabular}{cccc} 
Netral & 3 & 4 & 12 \\
Setuju & 4 & 4 & 16 \\
Sangat Setuju & 5 & 0 & 0 \\
Jumlah & & 9 & 30 \\
\hline \hline
\end{tabular}

Berdasarkan perhitungan menurut rumus skala Likert maka didapatkan hasil sebagai berikut ini.

$$
Y=\frac{30}{45} \times 100 \%=67 \%
$$

Berdasarkan hasil persentase nilai di atas, maka dapat disimpulkan bahwa berdasarkan pertanyaan yang diberikan, responden cukup tertarik dengan tampilan aplikasi secara keseluruhan. Hal ini dapat dilihat sesuai dengan Gambar 11 interval penilaian seperti berikut.

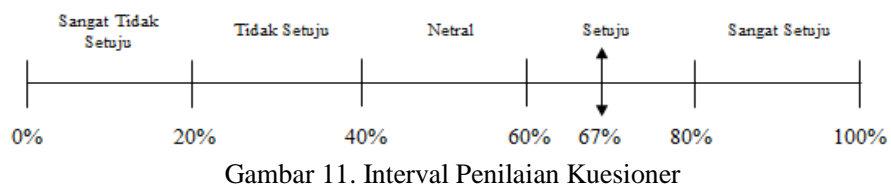

Tabel IV menunjukkan hasil pengujian kuesioner yang diberikan dengan sample pertanyaan tampilan Aplikasi "Belajar Angka dan Huruf Hijaiyah" sudah menyediakan media pembelajaran praktis dan menarik, setelah responden menggunakan aplikasi ini dan kemudian dihitung nilainya dengan menggunakan rumus skala Likert.

TABEL IV

HASIL PENGUJIAN KUESIONER

\begin{tabular}{ccccc}
\hline \hline Soal & Keterangan & Skor & Responden & Skor Responden \\
\hline 1 & $\begin{array}{c}\text { Sangat Tidak } \\
\text { Setuju } \\
\text { Tidak Setuju }\end{array}$ & 1 & 0 & 0 \\
Netral & 3 & 0 & 0 \\
Setuju & 4 & 4 & 12 \\
& & 5 & 20 \\
Sangat Setuju & 5 & 0 & 0 \\
Jumlah & & 9 & 32 \\
\hline \hline
\end{tabular}

Berdasarkan perhitungan menurut Rumus Likert maka didapatkan hasil sebagai berikut ini.

$$
Y=\frac{32}{45} \times 100 \%=71 \%
$$

Berdasarkan hasil persentase nilai di atas, maka dapat disimpulkan bahwa berdasarkan pertanyaan yang diberikan, responden setuju jika aplikasi ini praktis dan menarik sebagai media pembelajaran. Hal ini dapat dilihat sesuai dengan Gambar 12 interval penilaian seperti berikut.

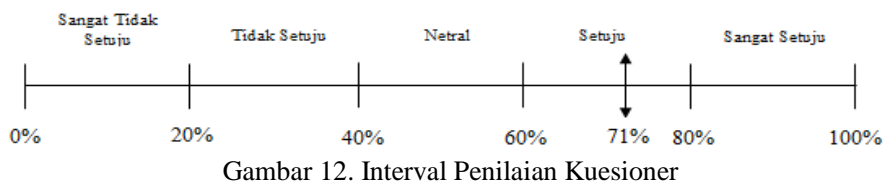

Tabel V menunjukkan hasil pengujian kuesioner yang diberikan dengan sample pertanyaan tampilan Aplikasi "Belajar Angka dan Huruf Hijaiyah" bernanfaat sesuai target pengguna, setelah responden menggunakan aplikasi ini dan kemudian dihitung nilainya dengan menggunakan rumus skala Likert

TABEL V

HASIL PENGUJIAN KUESIONER

\begin{tabular}{ccccc}
\hline \hline Soal & Keterangan & Skor & Responden & Skor Responden \\
\hline 1 & $\begin{array}{c}\text { Sangat Tidak } \\
\text { Setuju } \\
\text { Tidak Setuju }\end{array}$ & 1 & 0 & 0 \\
Netral & 3 & 0 & 0 \\
Setuju & 4 & 0 & 0 \\
& & 0 & 0 \\
Sangat Setuju & 5 & 9 & 45 \\
Jumlah & & 9 & 45 \\
\hline \hline
\end{tabular}

Berdasarkan perhitungan menurut Rumus Likert maka didapatkan hasil sebagai berikut ini.

$$
Y=\frac{45}{45} \times 100 \%=100 \%
$$

Berdasarkan hasil persentase nilai di atas, maka dapat disimpulkan bahwa berdasarkan pertanyaan yang diberikan, responden sangat setuju karena aplikasi bermanfaat sesuai target pengguna. Hal ini dapat dilihat sesuai dengan Gambar 13 interval penilaian seperti berikut.

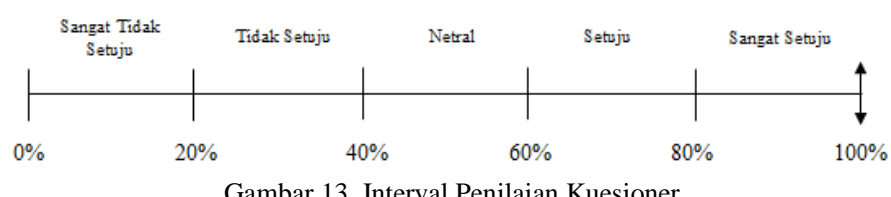

\section{Distribusi Permainan}

Agar banyak pengguna dapat memainkan permainan angka dan huruf hijaiyah ini, maka perlu dilakukan pendistribusian permainan. Tujuan dari pendistribusian permainan ini selain untuk menyebarkan permainan melalui jaringan juga untuk dapat menjadi sebuah evaluasi sehingga akan dapat mengembangkan sistem menjadi lebih baik lagi. Pendistribusian permainan ini dilakukan dengan mengubahnya menjadi berkas *.apk

\section{KESIMPULAN DAN SARAN}

Pada bagian ini akan dijelaskan kesimpulan dan saran dari hasil penelitian dan pembahasan.

\section{A. Kesimpulan}

Kesimpulan dari penelitian Tugas Akhir ini di antaranya sebagai berikut :

1) Permainan ini dibuat menggunakan Construct 2 dan dapat berjalan baik pada sistem operasi Android, serta hasil dari pengujian permainan dengan menggunakan metode blackbox mendapatkan hasil bahwa tombol-tombol dan fungsifungsi yang terdapat pada permainan dapat berfungsi dengan baik dan sesuai dengan fungsionalitasnya masingmasing. 
2) Permainan ini berisi tentang belajar angka dan huruf hijaiyah dalam sebuah aplikasi game.

3) Permainan ini dirancang dengan menggunakan tiga macam perancangan berbasis multimedia yaitu desain berbasis multimedia dengan menggunakan storyboard dan flowchart view, desain struktur navigasi dengan menggunakan diagram struktur navigasi dan desain berorientasi objek dimana menunjukkan objek-objek yang ada pada setiap Layout melalui diagram.

4) Berdasarkan hasil olahan data kuesioner dari 9 orang yang diambil sebagai responden menunjukkan angka $64 \%$ $100 \%$ terkait dengan 4 sample pertanyaan maka responden setuju dengan pembuatan aplikasi "Belajar Angka dan Huruf Hijaiyah" ini.

5) Permainan dapat dijalankan pada sistem operasi android dengan cara melakukan instalasi aplikasi file dengan format .apk terlebih dahulu sebelum memainkannya.

6) Permainan ini dibuat berbasis media pembelajaran interaktif dikhususkan untuk anak-anak dengan jenjang pendidikan Taman Kanak-Kanak dan Sekolah Dasar.

\section{B. Saran}

Saran yang dapat diberikan oleh penulis adalah sebagai berikut :

1) Permainan yang sudah dibuat sudah berjalan dengan baik sesuai dengan tujuan awal namun masih perlu dilakukan penelitian lanjutan untuk pengembangan permainan ini.

2) Penambahan animasi pada pergerakan masing-masing objek agar terlihat permainan lebih hidup dan efek pada gambar agar tampilan terlihat lebih menarik dan pengguna tidak merasa bosan dengan aplikasi ini.

\section{DAFTAR PUSTAKA}

[1] Izzan, Ahmad. 2004. Metodologi Pembelajaran Bahasa Arab. Bandung : Humaniora.,h, 98.

[2] Sutopo, A.H. 2012. Teknologi Informasi dan Komunikasi dalam Pendidikan. Yogyakarta: Graha Ilmu.

[3] Turban, 2002, Aplikasi Multimedia Interaktif dan Paradigma, Yogyakarta

[4] Vaughan, Tay, Multimedia : Making It Work. Edisi 6, Penerbit Andi Offset, Yogyakarta Tahun 2010.

[5] Dodit S. dan R. Agustina, Pemrograman Aplikasi Android, hal 14.

[6] Sutopo, A.H. 2003. Multimedia Interaktif dengan Flash. Graha Ilmu. Yogyakarta.

[7] Tatang M.A. 2010, Skala Likert : Penggunaannya dan Analisis Datanya.

[8] Pedoman Transliterasi Arab-Latin Berdasarkan SKB Menteri Agama dan Menteri P\&K RI no. 158/1987 dan No. 0543 b/U/1987 tertanggal 22 Januari 1988.

[9] ---,Computer Networks, http://audacity.sourceforge.net, 7 Agustus 2014

[10] ---,Computer Networks, http://graphicssoft.about.com, 7 Agustus 2014 